\title{
THE CIRCULATING RED CELL AND PLASMA VOLUME AND THE DISTRIBUTION OF BLOOD IN LARGE AND MINUTE VESSELS IN EXPERIMENTAL SHOCK IN DOGS, MEASURED BY RADIOACTIVE ISOTOPES OF IRON AND IODINE ${ }^{1}$
}

\author{
By JOHN G. GIBSON, 2ND, ARNOLD M. SELIGMAN, WENDELL C. PEACOCK \\ JACOB FINE, JOSEPH C. AUB, AND ROBLEY D. EVANS \\ (From the Departments of Medicine and Surgery, Harvard Medical School, the Medical \\ Clinics of the Peter Bent Brigham and the Massachusetts General Hospitals, and \\ the Surgical Research Department of the Beth Israel Hospital, Boston; \\ and the Radioactivity Center, Massachusetts Institute of Tech- \\ nology, Cambridge)
}

(Received for publication September 25, 1946)

During World War I a recently developed dye method of measuring plasma volume (1) was employed, to a limited extent, in the investigation of hemorrhagic and traumatic shock in wounded soldiers. Those studies ( 2 to 4 ) showed that shock was associated with varying degrees of reduction in the measurable total blood volume. It was assumed that this reduction resulted in a decreased venous return to the heart, which accounted for diminished blood flow and death in vascular collapse. It was also felt that severity of shock as judged clinically was proportional to the degree of blood volume reduction. Cannon (5) summarized the results of these investigations in 1923. There was little change in this conception of the fundamentals of shock for several years, and, as might be expected, little improvement in the therapy of shock.

Blalock(6) concluded that the decrease in blood pressure in experimental traumatic shock was due to loss of blood into damaged areas, or to hemorrhage into the intestinal tract (7). Moon (8) on the basis of pathological observations on dogs dying in prolonged shock (peritonitis) concluded that increase in capillary permeability permitting the leakage of plasma from the vascular bed was chiefly responsible for loss in blood volume.

1 The work described in this paper was done under contracts recommended by the Committee on Medical Research, between the Office of Scientific Research and Development and the Massachusetts Institute of Technology, in collaboration with the Peter Bent Brigham Hospital, Harvard University, the Beth Israel Hospital, the Massachusetts General Hospital, and the Huntington Memorial Hospital.
As improvements in the original dye method of measuring plasma volume became available ( 9 to 11), attention was again concentrated on blood volume in shock. It was shown (12) that surgical operations may be accompanied by a loss of plasma and red cells greater than can be accounted for by measured blood loss. A reduction in blood volume severe enough to produce severe peripheral vascular collapse was found to be brought about by the excessive sweating accompanying artificially induced fever (13). It was observed for the first time that shock produced in dogs by thermal burns was preceded by great reductions in circulating plasma volume $(14,15)$.

Hemoconcentration of blood in large vessels has been associated with shock, and was thought to be characteristic. Scudder (16) suggested that the determination of the specific gravity of whole blood and plasma might be useful as a guide to therapy.

Interest in the hemodynamics of shock came into a renewed focus during the early years of World War II. An extensive historical review of our knowledge of shock was published by Harkins in 1941 (17) and a briefer summary of the known physiology of shock by Wiggers in 1942 (18).

The many blood volume studies in experimental shock in animals (19) and of traumatic shock in man (20 to 22) carried out during the war have amply confirmed the early conception that severe oligemia is a constant characteristic of the condition.

That significant leakage of plasma from capillaries whose permeability is increased in shock does not occur, has been clearly demonstrated by 
Fine and Seligman (23 to 25). The opinion has been expressed by Noble and Gregersen that the reduction in blood volume is due to loss of whole blood at the site of injury (22). Since their subjects were accident cases, and the extent of blood loss suffered could be calculated only on the basis of blood volume measured after recovery, these observations do not indicate whether or not the entire reduction of blood volume as measured in shock could be accounted for by loss of blood into the various sites of injury.

Early in the course of our work we noted that the circulating red cell volume, as measured by the specific method of injecting red cells tagged with radioactive iron, was always some 15 per cent less than when measured by the dye plasma hematocrit method (26). This led us to question to some extent the reported changes in circulating red cell volume obtained by the latter method. Furthermore, our early studies in hemorrhagic shock in dogs, in which there was no evidence at autopsy of internal bleeding, consistently showed a reduction in circulating red cell volume greater than the cell volume removed, whereas dogs bled only moderately, and in whom shock symptoms did not occur, did not exhibit such a deficit in circulating red cells. This deficit was termed "trapping."

Root (27) and Chambers (28) made microscopic observations of capillary circulation in the mesentery of rats and dogs. Both observers noted that after severe hemorrhage, intestinal manipulation, and occlusion of blood flow in the leg, numerous plexi of capillaries contained closely packed erythrocytes at a complete standstill, the cells in circulation flowing through the larger arteriovenous shunts. This suggested that some portion of the red cells found to be "trapped" in our hemorrhaged dogs might still be within the vascular bed, and yet be temporarily isolated from the main course of the circulating blood. It was of interest to know where in the capillaries of the various organs such "trapping" might occur, and to what extent it might progress in relation to the clinical signs of impending, early or late shock.

Methods previously described (29) had enabled us to measure the quantity of red cells and plasma within the minute vessels of the organs in relation to the total circulating red cell and plasma volume. We concluded from these studies that
(1) all erythrocytes were in active circulation at all times; (2) 17 per cent of the total blood volume was within the capillaries; (3) there are pronounced gradients in the hematocrit of whole blood as it flows from larger to smaller vessels; and (4) that there are no significant reserves of red cells in the body of the normal dog.

The purpose of the experiments herein reported was to (1) measure reductions in red cells and plasma volume in a variety of experimental shock conditions, (2) determine the degree of "trapping" of red cells in shock, (3) locate if possible the site of red cell trapping, and (4) determine the extent of disturbance in normal capillary flow in early, reversible and irreversible shock.

\section{METHODS}

Plasma volume was determined by the method of Gibson and Evelyn (30), red cell volume by the method of Gibson and Peacock (31). Intravascular measurements of hemoglobin (25) and of radioactive iodine (25) were made as described by Fine and Seligman.

\section{MATERIAL STUDIED}

Shock was experimentally induced in normal healthy (stray) dogs by hemorrhage, muscle trauma with and without hemorrhage (Blalock crusher) (32), muscle ligation (33), occlusion of blood flow in extremities (tourniquets) (34), burns (flame (14) and hot water) and toxins (Shiga (35) and Clostridium (36)). Morphine narcosis and, in a few cases, nembutal anesthesia were used. Clinical condition of animals was followed by changes in mean arterial pressure, obtained by cannulation of a femoral or carotid artery, registered with mercury manometer.

Four groups of experiments were completed, here classified by the type of blood volume measurements carried out.

Series I. Total plasma (dye) and circulating red cell volumes (radio-iron) in the normal state, and during periods of lowered arterial pressure (shock), were determined. Some of these animals received plasma or albumin therapeutically.

Series II. In addition to the observations made in Series I, the quantity of total (by hemoglobin or $\mathrm{Fe}^{\mathrm{s}}$ measurements) and circulating (by $\mathrm{Fe}^{\mathrm{s}}$ ) red cells within the minute vessels of several organs was determined.

Series III. In addition to the observations made in Series I and II, the quantity of circulating plasma (by radio-iodo-protein) within the minute vessels was determined.

Series IV. Initial circulating cell and plasma volume was determined when the animals were in shock induced by tourniquets applied to both hind legs for 9 hours. These animals were treated with varying quantities of bovine albumin in 5 per cent and 25 per cent solution. A 
repeat cell and a plasma volume were determined at varying intervals after the albumin infusion.

\section{Series I. Gross volume studies.}

Determinations were carried out in dogs in whom shock was experimentally induced as follows:

Hemorrhage:

Controls-Bled for samples only-2 dogs.

Moderate bleeding but not to shock level-1 dog.

Severe bleeding to shock levels-10 dogs.

Severely bled, treated with dog plasma-2 dogs.

Severely bled, treated with bovine albumin -1 dog.

Severely bled, treated with whole dog blood transfusion-1 dog.

Muscle trauma :

Blalock crusher-3 dogs.

Ligation of both gastrocnemii-1 dog.

Bilateral occlusion tourniquets-1 dog.

Burns :

Flame, treated with bovine albumin-3 dogs.

Water $\left(98^{\circ}\right.$ F. $)-1$ dog.

Bacterial toxins: 2

Shiga toxin-2 dogs.

Clostridium toxin-1 dog.

In all of these experiments, the plasma and red cell volumes were determined prior to the experimental procedure. The total quantity of blood withdrawn, in both sampling and intentional and accidental hemorrhage, and the hematocrit of that blood were measured. The net loss of plasma and cells was taken as the quantities of plasma and cells removed minus the quantities of plasma and tagged red cells given (as whole blood) for radioiron cell volume measurements. The difference between initial and net loss of plasma and cells was termed the "expected volume." Repeat volume measurements, termed "found," were made in shock. If the found cell or plasma volume was less than the expected values, these discrepancies were termed "trapped"; if greater than the expected values, they were termed "mobilized." The quantity of trapped cells of plasma was expressed as a percentage of the expected volumes. Auricular, arterial, or venous hematocrits were measured directly. The average body hematocrit was calculated from total circulating plasma volume and red cell volume as measured by radio-iron.

\section{Series II.}

In 5 dogs the total and circulating red cells (but not plasma) within the minute vessels were measured, as described above. In addition, circulating red cell volume was measured in the normal and later in the shocked state.

Two animals were bled about $1 / 3$ and $1 / 2$ of their blood volume, and died in shock. One dog had both gastrocnemii ligated, was also bled and died in shock. Two dogs received Shiga toxin, and had moderate hemorrhages. Both were sacrificed, one before the onset of peripheral collapse and the other in deep shock.

2 Experiments in collaboration with Freedberg, Haimovici and Blumgart (35).

\section{Series III.}

In 5 morphinized dogs, the total and circulating red cells, and the circulating plasma (by radio-iodo-protein) were measured, as described above, in addition to measurements of total circulating red cells and plasma in the normal and later in the shocked state.

Two animals were bled, one (25-128) moderately, and one (25-116) severely. Both were sacrificed before the onset of extreme peripheral collapse. Dog 25-129 was bled as previously described (37), a mean arterial pressure of below $30 \mathrm{~mm}$. $\mathrm{Hg}$ being maintained for 3 hours; all of his own blood was then returned, and a large transfusion was given $(800 \mathrm{ml}$.). The initial red cell and plasma volumes were determined after the transfusion. The blood transfusion was of no benefit, and the animal was sacrificed terminally. Dog $25-130$ had both hind legs burned with water at $98^{\circ} \mathrm{F}$. and was sacrificed in extremis. Occlusion tourniquets were applied to both hind legs of dog 25-132 for 9 hours, and the animal was in deep shock when sacrificed.

Series IV.

A series of 16 morphinized dogs, in whom deep shock was produced by the application of tourniquets to both legs for 9 hours, was treated with intravenous bovine albumin solutions (34). All of these animals had marked hemoconcentration, the hematocrits all being above 60 , and mean arterial pressure fell to below $70 \mathrm{~mm}$. $\mathrm{Hg}$ shortly after the release of the tourniquets. The auricular hematocrit was greatly lowered by the albumin, whether given in 5 per cent solution or 25 per cent solution, with or without additional fluid or salt. Circulating red cell volume was determined before and after the administration of albumin.

\section{RESULTS}

Series $I$.

The extent of trapping or mobilization of red cells or plasma, expressed as percentages of the expected final volume, found in all animals in this series is summarized in Table $I$.

In the control dogs, bled less than 10 per cent of total blood volume for sampling only, no trapping of cells or plasma was observed.

Of 11 dogs in hemorrhagic shock, bled a net of from 27 to 50 per cent of initial total blood volume, 10 showed trapping of red cells of from 4 to 48 per cent of the expected volume; 9 dogs showed trapping of plasma of from 8 to 43 per cent. One dog, excessively hydrated, showed mobilization of both red cells and plasma, and 1 animal treated with bovine albumin solution showed mobilization of plasma. The dog treated with a large whole blood transfusion (25-129) showed trapping of both red cells and plasma. 
TABLE I

Trapping of red cells (by radio-iron and dye methods) and of plasma (dye method) in experimental shock in dogs

\begin{tabular}{|c|c|c|c|c|c|}
\hline \multirow{2}{*}{$\begin{array}{l}\text { Experi- } \\
\text { ment }\end{array}$} & \multirow{2}{*}{ Procedure } & \multicolumn{2}{|c|}{$\begin{array}{l}\text { Percentage } \\
\text { trapped }\end{array}$} & \multicolumn{2}{|c|}{$\begin{array}{c}\text { Percentage } \\
\text { mobilized }\end{array}$} \\
\hline & & Vrr* & $\mathrm{Vpd}^{*}$ & Vrr & Vpd \\
\hline $\begin{array}{l}135-9 \\
25-42 \\
25-128 \\
25-41 \\
25-45 \\
135-7 \\
135-8 \\
25-104 \\
25-105 \\
25-118 \\
25-120 \\
25-129 \\
25-119 \\
135-11 \\
135-15 \\
135-16 \\
135-90 \\
25-132 \\
131-39 \\
131-40 \\
131-41 \\
25-130 \\
\text { SA-2*** } \\
\text { SA-3*** } \\
135-136\end{array}$ & $\begin{array}{l}\text { Control } \\
\text { Control } \\
\text { After plasma } \\
\text { Hemorrhage } \\
\text { Hemorrhage } \\
\text { After plasma } \\
\text { Hemorrhage } \\
\text { After plasma } \\
\text { Hemorrhage } \\
\text { Hemorrhage } \\
\text { Hemorrhage-dehydrated } \\
\text { Hemorrhage-hydrated } \\
\text { Hemorrhage } \\
\text { Hemorrhage } \\
\text { Hemorrhage-whole blood } \\
\text { Hemorrhage-aibumin } \\
\text { Blalock crusher } \\
\text { Blalock crusher } \\
\text { Blalock crusher } \\
\text { Ligation of muscles } \\
\text { Tourniquets } \\
\text { Burn-albumin } \\
\text { Burn-albumin } \\
\text { Burn-albumin } \\
\text { Burn toxin } \\
\text { Shiga toxin } \\
\text { Shiga toxin } \\
\text { Clostridium toxin }\end{array}$ & $\begin{array}{r}12 \\
10 \\
4 \\
37 \\
11 \\
18 \\
22 \\
8 \\
15 \\
17 \\
48 \\
41 \\
11 \\
23 \\
9 \\
21 \\
\\
12 \\
10 \\
32 \\
15 \\
19 \\
16 \\
3 \\
44 \\
20\end{array}$ & $\begin{array}{r}11 \\
3 \\
7 \\
20 \\
20 \\
32 \\
19 \\
28 \\
43 \\
40 \\
9 \\
9 \\
8 \\
7 \\
9 \\
24 \\
24 \\
57 \\
24\end{array}$ & 63 & $\begin{array}{l}42 \\
86 \\
16\end{array}$ \\
\hline
\end{tabular}

* Vrr $=$ Red cell volume by radio-iron method.

Vpd = Plasma volume by dye method.

** Experiments in collaboration with Freedberg et al (35).

Two animals injured with the Blalock crusher showed trapping, and 1 showed mobilization of cells and plasma. Trapping of both cells and plasma also was found in a dog both of whose gastrocnemii were ligated, and in a dog in whom the blood flow to both hind legs had been occluded by tourniquets. All 4 burned dogs had extensive trapping of red cells, and 2 had trapping of plasma. Three of these, burned by flame, received bovine albumin, and 2 of these mobilized plasma.

Minimal trapping of red cells with mobilization of plasma was observed in $1 \mathrm{dog}(\mathrm{SA}-2)$ receiving Shiga toxin (not in shock) but another dog in severe shock showed extensive trapping of whole blood. The animal receiving Clostridium toxin trapped cells, but mobilized plasma.

\section{Series II.}

The unit quantities (ml. per gram) of total and circulating red cells in the minute vessels of the organs, and the ratio of circulating to total cells, are shown in Table II . Also shown are the percentages of expected total red cell volume represented by total and circulating red cells in the minute vessels of the entire organ masses analyzed. In addition, the quantity of trapped red cells found by gross volume measurements and the quantities found trapped in the minute vessels of the organ samples analyzed are shown.

With certain minor exceptions, the findings in the animal sacrificed while not in shock (SA-2) were at the lower limit of the normal range. The quantity of total and circulating red cells in the spleen was about $2 / 3$ the normal average, but within the normal range; and in the kidneys, about $1 / 3$ of normal. The percentage of expected red cell volume found as total and circulating cells in all the minute vessels was about normal. Trapping of cells by gross volume measurements was within the accepted limit of error, and no trapping was found in the minute vessels, the ratio $\mathfrak{f} 2$ being 1.00 .

In all 4 dogs in shock, the red cell content of the spleen, both total and circulating, was below normal, and only about $1 / 3$ to $2 / 3$ of this reduced content of cells was in active circulation. The spleen had been emptied of about $1 / 3$ of its normal red cell content.

Total red cell values were higher than normal in dog SA-3 (Shiga toxin), lower than normal in $\operatorname{dog}$ 25-120 (severe hemorrhage), but showed no marked deviation from normal in the other 2 dogs. The values for circulating red cells were definitely below normal (except in SA-3, in which they were high), and in virtually all instances were lower than the total cell values.

In all 4 dogs, the ratio of red cells actively circulating to those contained in the entire minute vessel bed was less than 1 , ranging from 0.76 to 0.83 , averaging 0.80 . In only one instance out of 26 was the $f 2$ value for an individual organ greater than one (1.03). Thus about $1 / 5$ of the total cells in the minute vesels were not in measurable circulation.

\section{Series III.}

The total and circulating red cell content, and circulating plasma and whole blood content of all the organs are given in Table III. The ratio ( $f 2$ ) of rapidly circulating to total red cells for indi- 


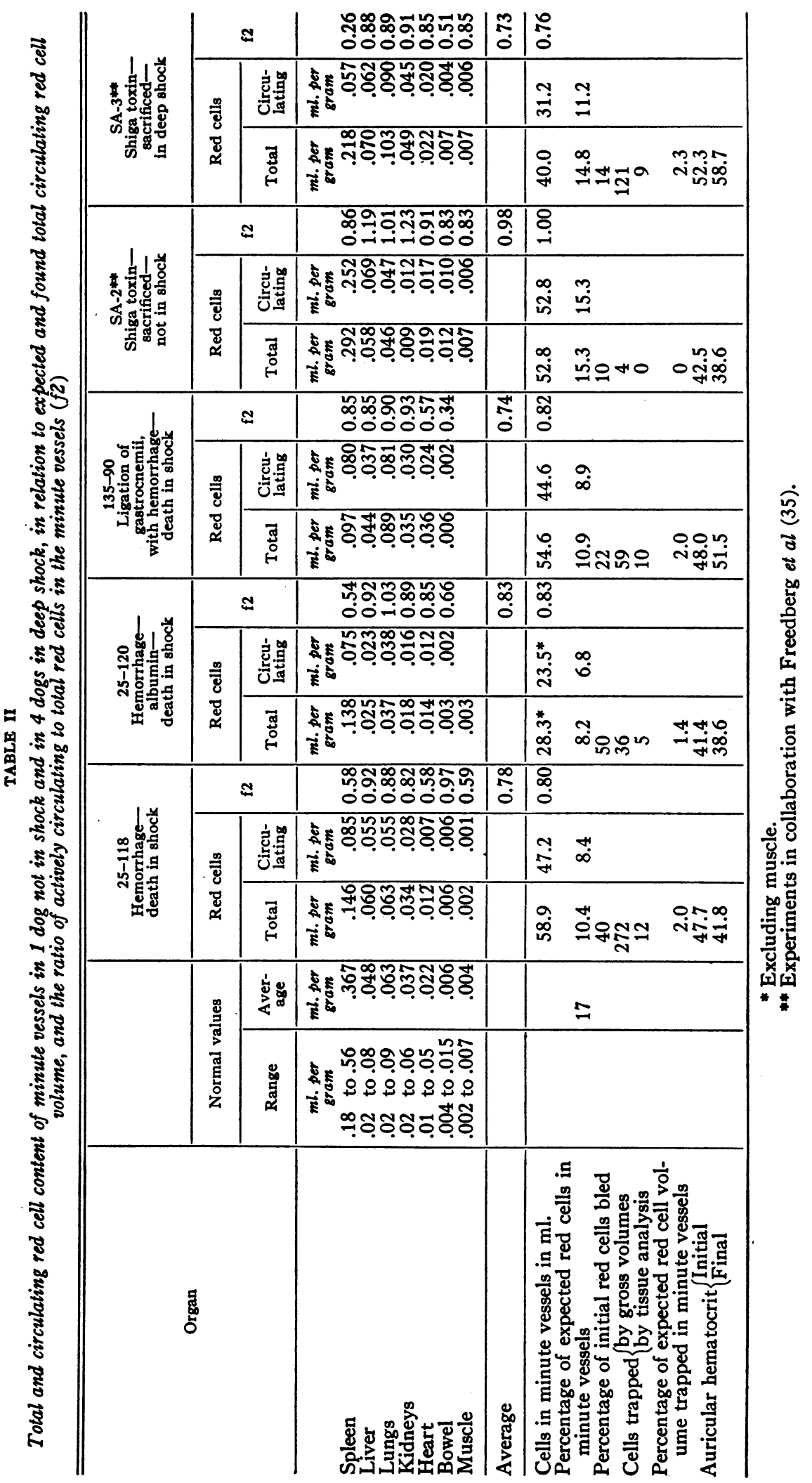


vidual organs, and for the entire organ masses analyzed; the percentage of expected as contrasted to circulating total red cell, plasma and whole blood volume found in the minute vessels; and the he- matocrits of whole blood in minute and large vessels and auricle are also shown.

Changes in total red cell and whole blood content of the spleens of the 4 animals in whom ob-

TABLE III

Total and circulating red cell content, and circulating plasma and whole blood content of minute vessels in 5 dogs in experimental shock, in relation to expected and found total circulating red cell, plasma and whole blood volumes, and the ratios of actively circulating to total red cells in the minute pessels

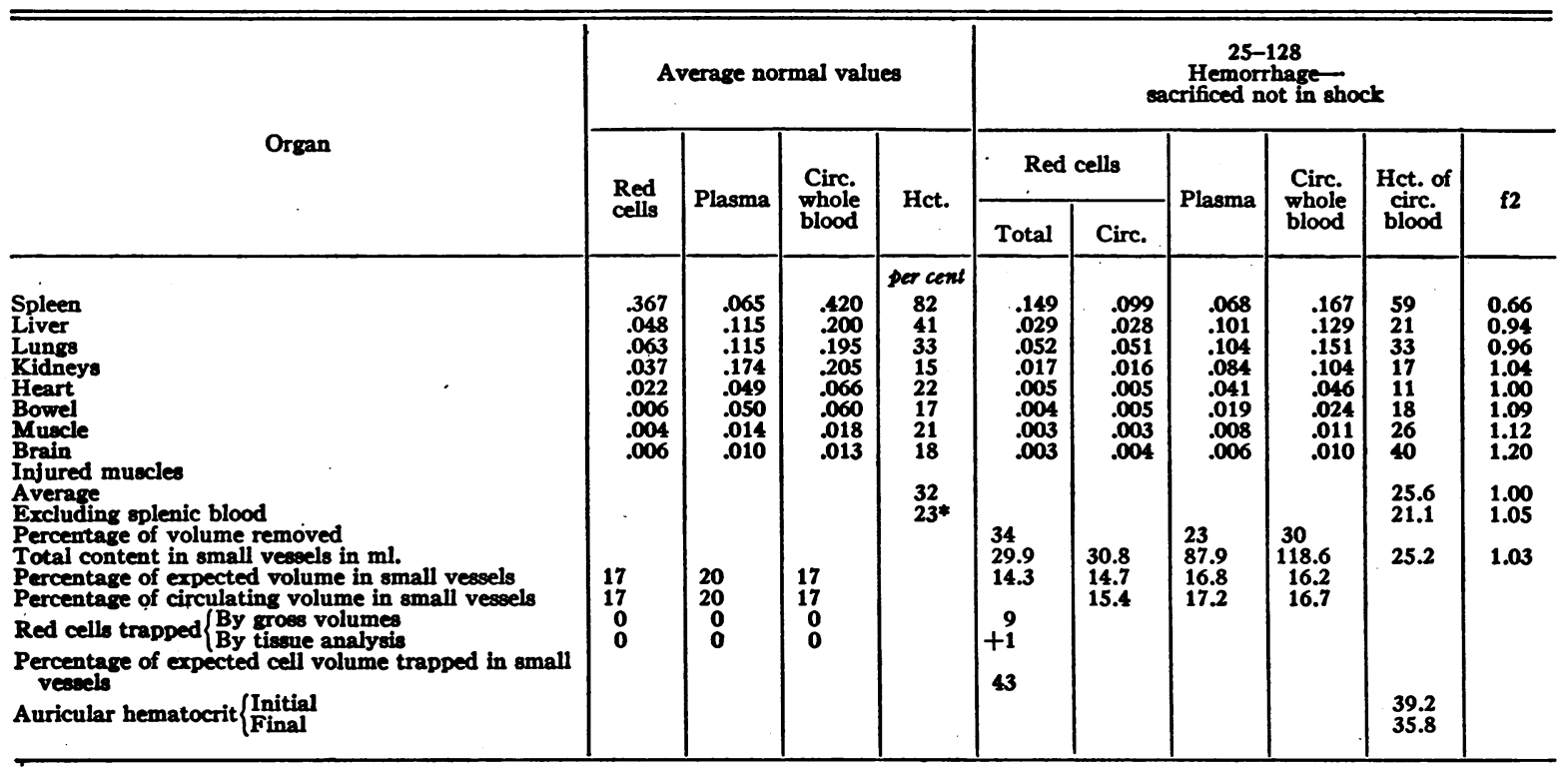

* Excluding splenic blood.

TABLE III-Continued

\begin{tabular}{|c|c|c|c|c|c|c|c|c|c|c|c|c|}
\hline \multirow{3}{*}{ Organ } & \multicolumn{6}{|c|}{$\begin{array}{c}25-116 \\
\text { Hemorrhage-- } \\
\text { sacrificed early in shock }\end{array}$} & \multicolumn{6}{|c|}{$\begin{array}{c}\text { Hemorrhage } \\
\text { Large transfusion- } \\
\text { sacrificed in shock }\end{array}$} \\
\hline & \multicolumn{2}{|c|}{ Red cells } & \multirow{2}{*}{ Plasma } & \multirow{2}{*}{$\begin{array}{l}\text { Circ. } \\
\text { whole } \\
\text { blood }\end{array}$} & \multirow{2}{*}{$\begin{array}{l}\text { Hct. } \\
\text { of } \\
\text { circ. } \\
\text { blood }\end{array}$} & \multirow{2}{*}{ f2 } & \multicolumn{2}{|c|}{ Red cells } & \multirow{2}{*}{ Plasma } & \multirow{2}{*}{$\begin{array}{l}\text { Circ. } \\
\text { whole } \\
\text { blood }\end{array}$} & \multirow{2}{*}{$\begin{array}{l}\text { Het. } \\
\text { of } \\
\text { circ. } \\
\text { blood }\end{array}$} & \multirow{2}{*}{ f2 } \\
\hline & Total & Circ. & & & & & Total & Circ. & & & & \\
\hline $\begin{array}{l}\text { Spleen } \\
\text { Liver } \\
\text { Lungs } \\
\text { Kidneys } \\
\text { Heart } \\
\text { Bowel } \\
\text { Muscle } \\
\text { Brain } \\
\text { Injured muscles } \\
\text { Average } \\
\text { Excluding splenic blood } \\
\text { Percentage of volume removed } \\
\text { Total content in small vessels in ml. } \\
\text { Percentage of expected volume in small vessels } \\
\text { Percentage of circulating volume in small } \\
\text { vessels } \\
\text { Red cells trapped }\left\{\begin{array}{l}\text { By gross volumes } \\
\text { By tissue analysis }\end{array}\right. \\
\text { Percentage of expected cell volume trapped in } \\
\text { omall vessels } \\
\text { Auricular hematocrit }\left\{\begin{array}{l}\text { Initial } \\
\text { Final }\end{array}\right.\end{array}$ & $\begin{array}{l}49 \\
39.4 \\
11.6 \dagger \\
13.9 \\
57 \\
7 \\
2.0\end{array}$ & $\begin{array}{l}.054 \\
.019 \\
.045 \\
.024 \\
.007 \\
.003 \\
.002\end{array}$ & \begin{tabular}{|l|}
.101 \\
.133 \\
.136 \\
.138 \\
.038 \\
.036 \\
.010
\end{tabular} & $\begin{array}{l}.155 \\
.152 \\
.181 \\
.162 \\
.045 \\
.039 \\
.012\end{array}$ & $\begin{array}{r}35 \\
12 \\
25 \\
16 \\
16 \\
8 \\
16 \\
\\
16.0 \\
15.2 \\
15.7\end{array}$ & $\begin{array}{l}0.15 \\
0.71 \\
1.12 \\
0.83 \\
1.74 \\
1.44 \\
0.61 \\
\\
1.08 \\
0.92 \\
0.82\end{array}$ & \begin{tabular}{|c}
0 \\
133.2 \\
21.6 \\
22.6 \\
25 \\
35 \\
5.7
\end{tabular} & $\begin{array}{l}.105 \\
.158 \\
.105 \\
.034 \\
.024 \\
.030 \\
.005 \\
.005\end{array}$ & $\begin{array}{l}.108 \\
.146 \\
.124 \\
.167 \\
.039 \\
.033 \\
.008 \\
.005\end{array}$ & $\begin{array}{l}.213 \\
.304 \\
.229 \\
.201 \\
.063 \\
.063 \\
.013 \\
.010\end{array}$ & \begin{tabular}{|l|}
48 \\
52 \\
46 \\
17 \\
38 \\
30 \\
38 \\
52 \\
40.1 \\
44.5 \\
44.6
\end{tabular} & $\begin{array}{l}0.75 \\
0.88 \\
1.18 \\
0.71 \\
0.86 \\
0.91 \\
0.45 \\
0.57 \\
0.78 \\
0.80 \\
0.74\end{array}$ \\
\hline
\end{tabular}


TABLE III-Continued

\begin{tabular}{|c|c|c|c|c|c|c|c|c|c|c|c|c|}
\hline \multirow{3}{*}{ Organ } & \multicolumn{6}{|c|}{$\begin{array}{l}25-130 \\
\text { Burn both hind legs- } \\
\text { sacrificed in deep shock. } \\
\text { (spleen not analyzed) }\end{array}$} & \multicolumn{6}{|c|}{$\begin{array}{l}25-132 \\
\text { Tourniquets both hind legs- } \\
\text { sacrificed in deep shock }\end{array}$} \\
\hline & \multicolumn{2}{|c|}{ Red cells } & \multirow{2}{*}{ Plasma } & \multirow{2}{*}{$\begin{array}{l}\text { Circ. } \\
\text { whole } \\
\text { blood }\end{array}$} & \multirow{2}{*}{$\begin{array}{l}\text { Hct. } \\
\text { of } \\
\text { circ. } \\
\text { blood }\end{array}$} & \multirow{2}{*}{ f2 } & \multicolumn{2}{|c|}{ Red cells } & \multirow{2}{*}{ Plasma } & \multirow{2}{*}{$\begin{array}{l}\text { Circ. } \\
\text { whole } \\
\text { blood }\end{array}$} & \multirow{2}{*}{$\begin{array}{l}\text { Hct. } \\
\text { of } \\
\text { circ. } \\
\text { blood }\end{array}$} & \multirow{2}{*}{ f2 } \\
\hline & Total & Circ. & & & & & Total & Circ. & & & & \\
\hline $\begin{array}{l}\text { Spleen } \\
\text { Liver } \\
\text { Lungs } \\
\text { Kidneys } \\
\text { Heart } \\
\text { Bowel } \\
\text { Muscle } \\
\text { Brain } \\
\text { Injured muscles } \\
\text { Average } \\
\text { Excluding splenic blood } \\
\text { Percentage of volume removed } \\
\text { Total content in small vessels in ml. } \\
\text { Percentage of expected volume in small vessels } \\
\text { Percentage of circulating volume in small } \\
\text { vessels } \\
\text { Red cells trapped }\left\{\begin{array}{l}\text { By gross volumes } \\
\text { By tissue analysis }\end{array}\right. \\
\text { Percentage of expected cell volume trapped in } \\
\text { small vessels } \\
\text { Auricular hematocrit }\left\{\begin{array}{l}\text { Initial } \\
\text { Final }\end{array}\right.\end{array}$ & $\begin{array}{c}.048 \\
.069 \\
\\
.021 \\
\\
.009 \\
.006 \\
.018 \\
. \\
+3 * \\
73.1 \\
16.4 \\
19.5 \\
72 \\
43 \\
9.7\end{array}$ & $\begin{array}{r}.017 \\
.052 \\
.025 \\
.014 \\
\\
.005 \\
.005 \\
.005 \\
\\
+2 * \\
30.0 \\
6.7 \\
8.1\end{array}$ & $\begin{array}{r}.112 \\
.127 \\
.144 \\
.045 \\
\\
.010 \\
.010 \\
.013 \\
\\
+2 * \\
99.9 \dagger \\
15.2 \\
18.1\end{array}$ & $\begin{array}{l}.129 \\
.179 \\
.169 \\
.059 \\
.015 \\
.015 \\
.018\end{array}$ & $\begin{array}{l}13 \\
29 \\
14 \\
23 \\
32 \\
26 \\
26 \\
23 \\
\\
23.2\end{array}$ & $\begin{array}{l}0.35 \\
0.75 \\
0.67 \\
0.52 \\
0.78 \\
0.26 \\
0.60 \\
\\
0.41\end{array}$ & $\begin{array}{c}.083 \\
.046 \\
.084 \\
.058 \\
.029 \\
.009 \\
.008 \\
.009 \\
.032 \\
\\
2 \\
105.6 \\
16.6 \\
18.2 \\
55 \\
23 \\
8.7\end{array}$ & $\begin{array}{l}.039 \\
.032 \\
.081 \\
.053 \\
.027 \\
.010 \\
.008 \\
.007 \\
.011\end{array}$ & \begin{tabular}{|r|}
.073 \\
.081 \\
.118 \\
.157 \\
.035 \\
.018 \\
.007 \\
.005 \\
.013 \\
\\
2 \\
112.8 \\
12.5 \\
29.6
\end{tabular} & $\begin{array}{r}.112 \\
.113 \\
.199 \\
.210 \\
.062 \\
.028 \\
.015 \\
.012 \\
.024 \\
\\
2 \\
195.6 \\
12.5 \\
20.4\end{array}$ & $\begin{array}{l}34 \\
28 \\
41 \\
25 \\
44 \\
35 \\
55 \\
54 \\
50 \\
42 \\
43 \\
42.3\end{array}$ & $\begin{array}{l}0.47 \\
0.67 \\
0.99 \\
0.91 \\
0.93 \\
1.05 \\
1.13 \\
0.81 \\
0.34 \\
0.87 \\
0.92 \\
0.79\end{array}$ \\
\hline
\end{tabular}

* Quantity of blood given for volume determination exceeded amount lost in sampling.

$\uparrow$ Excluding spleen and bowel.

servations were made were striking. The total cell content was reduced by from 60 to 80 per cent, the plasma content remaining unchanged. Here again, as in Series II, the spleen had emptied about 20 per cent of the normal total minute vessel red cell content into the blood stream.

In both the untreated bled dogs, the total red cell content of minute vessels of all organs was well below normal. The lowest values were observed in the most severely bled animal, in whom circulating red cell contents were still lower.

Plasma content values were consistently about $2 / 3$ of normal in all organs of the dog not in shock, but in the dog in early shock values for lung, liver and kidney were higher than normal, being elsewhere about normal. Whole blood values for all organs were below normal in both animals.

The animal receiving the large transfusion had higher than average normal total cell values in all organs, and higher than normal circulating cell values in liver, lungs and kidneys. Plasma values were at essentially normal levels. Whole blood values were above normal in liver and lungs, but otherwise were about normal.

The burned animal showed practically no deviation from average normal total cell content in the organs analyzed, but all values for circulating cells were low (no data were obtained on spleen, kidneys and bowel). Plasma values were on the low side, and whole blood values reflected the diminution in circulating cells and plasma.

In the animal with shock produced by tourniquets, total cell content values of all organs were consistently high, the circulating cell values approximating the normal range. Plasma values were low, to such an extent that the whole blood values were slightly below normal in spite of the high cell contents.

In this series, in 7 out of 28 instances $\mathrm{f} 2$ ratios greater than 1.0 were obtained. The weighted $\mathrm{f} 2$ value was 1.03 in the dog not in circulatory collapse, but in the 4 shocked animals values ranged from 0.60 to 0.82 , averaging 0.74 . In this series, as in Series II, about 20 per cent of the total cells within the minute vessels were not in active circulation.

\section{Series IV.}

In this series less than 10 per cent of the circulating red cell volume found in shock was removed in net sampling. In every case, the auricular hematocrit, markedly elevated after removal of tourniquets, was considerably lowered following the administration of albumin. The circulating red cell volume after albumin was higher than the expected volume (volume in shock less net loss in 
sampling) in 10 dogs, showed no change in 4 dogs, and was lower in 2 dogs. Of the 10 showing an increase, the change was less than 10 per cent in 4, between 5 and 10 in 4 , and over 10 per cent in 2 dogs.

Eight dogs survived more than 24 hours, after the removal of tourniquets (later to die of infection or be sacrificed), and 8 died within 24 hours. All of the 8 survivors showed increases over expected cell volume, but 2 that showed increases died. None of the animals that died showed an increase over expected volume, and 2 had decreases after therapy. Changes in circulating red cell volume, auricular hematocrit and mean arterial pressure are given in Table IV.

\section{DISCUSSION}

Virtually all of the animals in Series I, in which only gross red cell and plasma volume measurements were made, had reductions in total blood volume. In addition, they showed varying degrees of trapping of both red cells and plasma.

Considered by etiology of shock, the animals given bacterial toxins showed approximately 50 per cent trapping of red cells; those burned, 20 per cent; those whose muscles were injured, 15 per cent; those with severe or fatal hemorrhage, 25 per cent; and those whose blood loss was treated (without avail) with whole blood or protein solutions, 15 per cent. The majority of these animals underwent severe reductions in mean arterial and pulse pressure, and blood flow was markedly slowed, but, as far as the clinical condition of the animal could be judged by these observations, there was no obvious relationship between the degree of trapping and mean arterial pressure levels.

Some bled animals underwent hemodilution, as evidenced by a fall in auricular hematocrit, and some hemoconcentration, with a rise in auricular hematocrit. The burned animals (treated with albumin, and untreated) showed no marked change in hematocrit ; those whose muscles were damaged showed considerable hemoconcentration, while those receiving toxins showed variable changes in hematocrit. There was no consistent relationship between the direction of, or degree of, change in hematocrit and the percentage of total red cell volume found to be trapped.

All of these animals underwent varying degrees of net loss of whole blood due to intentional bleeding or sampling. The findings cited above, however, indicate that characteristically, in shock,

TABLE IV

Changes in auricular hematocrit, mean arterial pressure and circulating red cell volume after treatment of shock induced by bilateral tourniquets with albumin solutions

\begin{tabular}{|c|c|c|c|c|c|c|c|c|c|c|c|}
\hline \multirow{2}{*}{$\begin{array}{l}\text { Exp. } \\
\text { no. }\end{array}$} & \multirow{2}{*}{ Wght. } & \multirow{2}{*}{$\underset{\text { i.v. }}{\text { Albumin }}$} & \multicolumn{2}{|c|}{ Hematocrit } & \multicolumn{3}{|c|}{ Red cell volume } & \multicolumn{2}{|c|}{ Change in cell volume } & \multirow{2}{*}{$\begin{array}{l}\text { Change in } \\
\text { m.a.p. }\end{array}$} & \multirow{2}{*}{ Result } \\
\hline & & & Before & After & Before & Expected & After & + & - & & \\
\hline $\begin{array}{r}2 \\
4 \\
12 \\
13 \\
17 \\
19 \\
21 \\
6 \\
8 \\
27 \\
38 \\
41 \\
31 \\
33 \\
45 \\
47\end{array}$ & $\begin{array}{r}\text { kgm. } \\
12.7 \\
6.4 \\
11.3 \\
18.2 \\
12.7 \\
13.2 \\
10.0 \\
7.8 \\
11.4 \\
7.7 \\
12.3 \\
9.1 \\
13.2 \\
7.7 \\
13.2 \\
13.2 \\
26.4\end{array}$ & $\begin{array}{r}m l . \\
500 \\
400 \\
500 \\
615 \\
1,600 \\
1,000 \\
600 \\
80 \\
110 \\
75 \\
240 \\
75 \\
260 \\
155 \\
265 \\
500\end{array}$ & $\begin{array}{c}\text { per cent } \\
77 \\
62 \\
64 \\
69 \\
70 \\
67 \\
82 \\
85 \\
55 \\
77 \\
77 \\
67 \\
67 \\
65 \\
71 \\
62\end{array}$ & $\begin{array}{c}\text { per cent } \\
45 \\
57 \\
43 \\
39 \\
32 \\
32 \\
62 \\
57 \\
40 \\
56 \\
55 \\
48 \\
31 \\
34 \\
52 \\
40\end{array}$ & $\begin{array}{r}m l . \\
530 \\
380 \\
500 \\
760 \\
505 \\
550 \\
485 \\
445 \\
515 \\
370 \\
505 \\
315 \\
460 \\
250 \\
605 \\
1,080\end{array}$ & $\begin{array}{c}m l . \\
480 \\
355 \\
455 \\
700 \\
485 \\
485 \\
435 \\
450 \\
475 \\
340 \\
480 \\
295 \\
415 \\
220 \\
595 \\
1,060\end{array}$ & $\begin{array}{c}m l . \\
510 \\
395 \\
540 \\
760 \\
500 \\
495 \\
435 \\
450 \\
475 \\
335 \\
480 \\
220 \\
430 \\
230 \\
640 \\
1,105\end{array}$ & $\begin{array}{c}\text { per cent } \\
5.7 \\
11.2 \\
18.7 \\
8.6 \\
3.1 \\
2.1 \\
0 \\
0 \\
0 \\
0 \\
\\
3.2 \\
4.5 \\
7.5 \\
5.2\end{array}$ & $\begin{array}{r}1.3 \\
25.4\end{array}$ & $\begin{array}{r}m m . H g \\
+60 \\
0 \\
+10 \\
+50 \\
+50 \\
+50 \\
-40 \\
-20 \\
+50 \\
-10 \\
+20 \\
-10 \\
+40 \\
+40 \\
+45 \\
+30\end{array}$ & $\begin{array}{l}\text { S } \\
\text { S } \\
\text { S } \\
\text { S } \\
\text { D } \\
\text { D } \\
\text { D } \\
\text { D } \\
\text { D } \\
\text { D } \\
\text { D } \\
\text { D } \\
\text { S } \\
\mathbf{S} \\
\mathbf{S} \\
\mathbf{S}\end{array}$ \\
\hline
\end{tabular}

Dogs 2 to 21 inclusive received 5 per cent albumin in 0.85 per cent $\mathrm{NaCl}$.

Dogs $6,8,27,38$ and 41 received 25 per cent albumin with no additional fluid.

Dogs 31 and 33 received 25 per cent albumin plus saline by stomach tube.

Dogs 45 and 47 received 25 per cent albumin plus 0.5 gram $\mathrm{NaCl}$ per $100 \mathrm{ml}$. plus water by stomach tube.

$\mathrm{S}=$ Survived 24 hours or more after release of tourniquets.

$\mathrm{D}=$ Died within 24 hours of release of tourniquets. 
there is a greater reduction in circulating cells and plasma than can be accounted for by known external blood loss.

This discrepancy may be accounted for in 2 ways: (1) loss of cells and plasma from the vascular tree through internal bleeding into damaged areas, serous cavities or hollow viscera, and (2) isolation from the moving blood stream of cells and plasma that remain within some portion of the vascular tree. Evidence of the former phenomenon should be obtained at necropsy. Evidence of the latter phenomenon was found in the experiments in Series II and III.

There were 2 dogs in these series not in shock (SA-2 and 25-128), and they served as controls for the shocked animals. Other than reductions in blood volume due to known blood loss, neither dog showed any significant deviation from the normal. The percentage of total red cell, plasma and whole blood volume found within the minute vessels of individual organs, the ratio of rapidly circulating to total red cells in minute vessels, and the ratio of the hematocrit of blood in minute and large vessels to the auricular hematocrit were all within normal limits.
The shocked animals in these 2 series represent 1 case of early shock (25-116), 1 fatal hemorrhage (25-118), 2 cases of severe hemorrhage in which volume replacement with bovine serum albumin (25-120) and whole blood (25-129) was ineffective, 1 case of severe muscle trauma (135-90), and 1 case of arterial and venous occlusion (25132), both untreated and fatal in degree, 1 fatal burn (25-130), and 1 case in which death was due to an overwhelming toxin (SA-3).

Certain findings were common to all of these animals, although varying in degree, regardless of the etiology of their peripheral vascular collapse. Without exception, the unit values (ml. per gram) for total red cells in the spleen were well below normal values. In the other organs, values were above normal in the transfused dog (25-129) and the animal dying of Shiga toxin (SA-3). High values were chiefly in lungs and liver and kidneys. Low values were consistently found in all 3 animals that were bled. No significant change from normal was found in the other animals.

Unit values for plasma were below normal in the tourniquet dog (25-132), about normal in the bled dog not in shock, but above normal in the

TABLE V

Percentages (net) of cells, plasma and whole blood removed by hemorrhage; the expected and found red cell, plasma and whole blood volumes; and the quantities of total and circulating red cells within the minute vessels

\begin{tabular}{|c|c|c|c|c|c|c|c|c|c|c|c|c|c|c|c|}
\hline & \multicolumn{12}{|c|}{ Series II } & \multicolumn{3}{|l|}{ ' } \\
\hline & \multicolumn{3}{|c|}{$25-118$} & \multicolumn{3}{|c|}{$25-120$} & \multicolumn{3}{|c|}{$135-90$} & \multicolumn{3}{|c|}{ SA-2* } & \multicolumn{3}{|c|}{ SA-3* } \\
\hline & \multicolumn{3}{|c|}{$\begin{array}{l}\text { Hemorrhage- } \\
\text { death in shock }\end{array}$} & \multicolumn{3}{|c|}{$\begin{array}{l}\text { Hemorrhage- } \\
\text { death in shock }\end{array}$} & \multicolumn{3}{|c|}{$\begin{array}{l}\text { Ligation of } \\
\text { gastrocnemii- } \\
\text { death in shock }\end{array}$} & \multicolumn{3}{|c|}{$\begin{array}{l}\text { Shiga toxin- } \\
\text { not in shock }\end{array}$} & \multicolumn{3}{|c|}{$\begin{array}{l}\text { Shiga toxin- } \\
\text { eacrificed in } \\
\text { shock }\end{array}$} \\
\hline & C & $\mathbf{P}$ & $\mathbf{w}$ & C & $\mathbf{P}$ & $\mathbf{W}$ & C & $\mathbf{P}$ & $\mathbf{w}$ & C & $\mathbf{P}$ & $\mathbf{w}$ & C & $\mathbf{P}$ & $\mathbf{w}$ \\
\hline 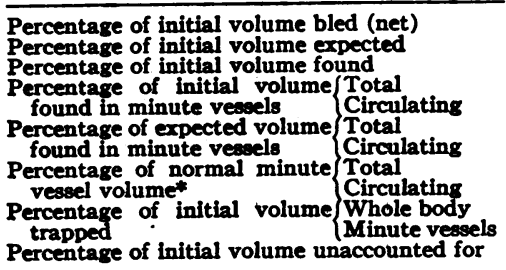 & \begin{tabular}{l|}
37 \\
63 \\
42 \\
6.6 \\
5.3 \\
10.4 \\
8.1 \\
61 \\
52 \\
21 \\
1.3 \\
19.7
\end{tabular} & $\begin{array}{l}41 \\
59 \\
55\end{array}$ & $\begin{array}{l}39 \\
61 \\
44\end{array}$ & \begin{tabular}{|l|}
49 \\
51 \\
46 \\
$4.2 *$ \\
$3.4 *$ \\
8.1 \\
6.7 \\
48 \\
39 \\
5 \\
0.6 \\
4.4
\end{tabular} & $\begin{array}{l}42 \\
58 \\
54\end{array}$ & $\begin{array}{l}44 \\
56 \\
51\end{array}$ & \begin{tabular}{c|}
22 \\
78 \\
68 \\
8.5 \\
7.0 \\
12.5 \\
10.3 \\
74 \\
61 \\
10 \\
0.9 \\
9.1
\end{tabular} & $\begin{array}{l}22 \\
78 \\
59 \\
\\
\\
19 \\
19\end{array}$ & $\begin{array}{l}15 \\
15\end{array}$ & \begin{tabular}{|c|}
$+2 *$ \\
102 \\
102 \\
16.1 \\
15.8 \\
16.1 \\
15.8 \\
93 \\
92 \\
+2 \\
0 \\
+2
\end{tabular} & $\begin{array}{r}-1 \\
99 \\
116 \\
\\
+16 \\
+16\end{array}$ & $\begin{array}{r}-1 \\
99 \\
110 \\
\\
+10 \\
+10\end{array}$ & \begin{tabular}{|c|}
5 \\
95 \\
54 \\
13.8 \\
10.7 \\
14.5 \\
11.3 \\
85 \\
66 \\
11 \\
0.3 \\
10.7
\end{tabular} & $\begin{array}{l}26 \\
26\end{array}$ & $\begin{array}{r}+2 \\
102 \\
64\end{array}$ \\
\hline $\begin{array}{l}\text { Normal percentage of total volume in minute } \\
\text { vessels: red cells 17, plasma 20, whole blood } \\
\text { 17. (See Table I) }\end{array}$ & \multicolumn{3}{|c|}{$\begin{array}{l}\text { Final Vrr in dy- } \\
\text { ing animal. } \\
\text { Determined value } \\
\text { may be falsely } \\
\text { high due to in- } \\
\text { complete mixing } \\
\text { of tagsed red } \\
\text { cells. }\end{array}$} & \multicolumn{3}{|c|}{$\begin{array}{l}\text { - Red cell content } \\
\text { of minute vessels } \\
\text { did not include } \\
\text { muscle. }\end{array}$} & \multicolumn{3}{|c|}{$\begin{array}{l}\text { Evidence of large } \\
\text { loss of cells and } \\
\text { plasma into mus- } \\
\text { cles at necropsy. }\end{array}$} & \multicolumn{3}{|c|}{$\begin{array}{l}\text { *Red cells given } \\
\text { for Vrr exceeded } \\
\text { net loss of cells } \\
\text { in sampling. }\end{array}$} & \multicolumn{3}{|c|}{$\begin{array}{l}110 \mathrm{ml} \text {. of bloody } \\
\text { fluid found in gut } \\
\text { at necropoy (19 } \\
\text { per cent of initial } \\
\text { whole blood vol- } \\
\text { ume). }\end{array}$} \\
\hline
\end{tabular}


TABLE v-Continued

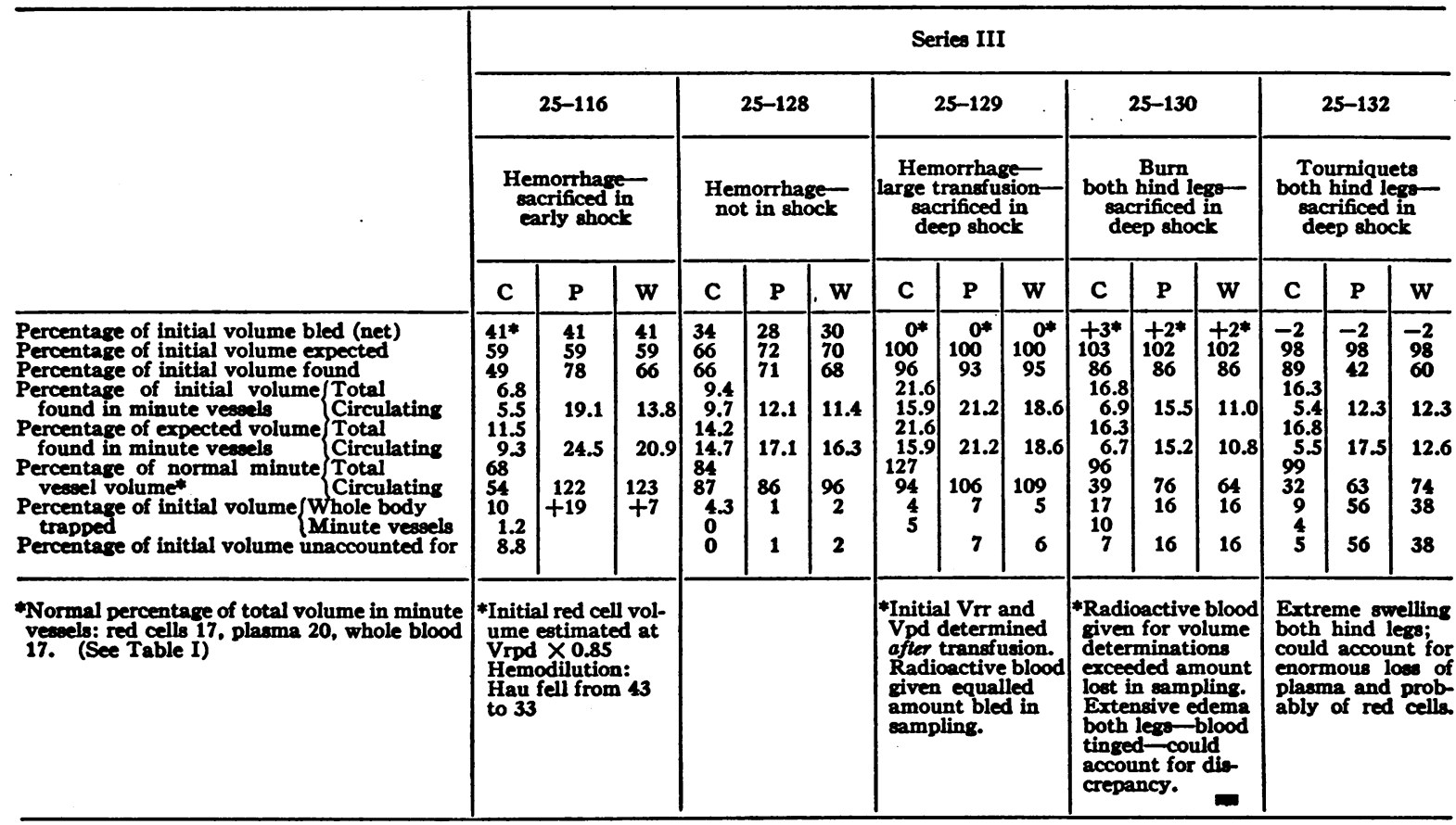

burned dog (24-130), and in both the dog in early hemorrhagic shock (25-116) and the transfused $\operatorname{dog}(25-129)$. In all animals in shock, the unit value of circulating red cells tended to be less than that of total red cells. In both series, a total of 69 organ samples were analyzed for total and circulating red cells. In only 10 instances was the ratio (f2) of rapidly circulating to total red cells

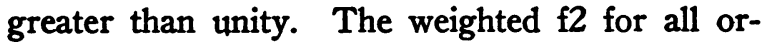
gans was less than 1 in all 8 animals dying or sacrificed in shock. These values ranged from 0.60 to 0.83 , averaging 0.76 . The lowest ratio occurred in the burned dog, the highest in the bled dog in early shock and the bled dog treated with bovine albumin. The values for the other 5 dogs were from 0.73 to 0.79 .

Thus from $1 / 3$ to $1 / 5$ of the red cells contained in the minute vessels throughout the body were not in active measurable circulation. This phenomenon was widespread, occurred in all the organs analyzed, and was not confined to sites of traumatic injury. The lowest $\mathrm{f} 2$ ratios were found in the muscles of the burned dog and the animal subject to occlusion tourniquets.

Since the techniques employed measure only red cells and plasma in active circulation, the findings reflect the state of blood flow through the minute vessel beds of the organs. It is apparent that in these shocked animals, the blood flow through all of the organs was reduced by from 20 to 40 per cent.

Thus another characteristic of shock is that, regardless of etiology, there is a widespread stagnation of red cells within the minute vessels of all of the organs in the body. The degree of this stagnation may be such as to indicate a reduction in blood flow through minute vessels to from 60 to 80 per cent of normal.

In Table V are listed for Series II and III (as percentages of initial volumes), the net amount of cells, plasma and whole blood removed by hemorrhage and sampling; the expected and found volumes; and the quantity of red cells, both total and actively circulating, measured as being within the vessels of the organs analyzed. These minute vessel red cell quantities are also expressed as percentages of the expected cell volume, and these in turn, as percentages of the fraction of total red cell volume normally found in circulation in the minute vessels. (See Table I for average normal values.) The percentage of expected cells, plasma and whole blood volume found trapped in the 
vascular bed (by gross volume measurements) and in the minute vessels (by tissue analyses) are also shown. Finally, the red cells, plasma and whole blood not accounted for by measured trapping within minute vessels, are expressed as percentages of both initial and expected volumes.

The plasma content of minute vessels was not determined in Series II.

Dog SA-2 experienced a negligible net loss of whole blood (a slight net gain in red cells), and the fraction of total red cells found in the minute vessels was almost normal, 93 per cent. Only 2 per cent of gross trapping of red cells was found, and all of the cells in the minute vessels were in active circulation.

In both the dogs that were severely bled (25118 and 120), the found volume of cells and plasma was less than expected. The fraction of the expected total red cell volume, found as total cells in the minute vessels, was below normal to a degree about equal to the net red cell loss, but the fraction found in active circulation was far lower than the percentage of cells lost. In both animals the gross volume trapping was far greater than that measured by organ analysis.

Dog SA-3 succumbed to the toxin and was in deep shock. Net blood loss was little, but the found cell and plasma volume was much less than expected. The minute vessels contained only 85 and 66 per cent of the expected total and circulating cell volume. Only a fraction of the total trapping was found in the minute vessels. The gut contained a large quantity of bloody fluid at necropsy.

Dog 135-90 experienced moderate blood loss in addition to trauma, and again the found red cell and plasma volume was considerably lower than the expected. The reduction from normal in fraction of expected total cells in the minute vessels was greater than the percentage of initial red cell volume removed, and the reduction of circulating cells was even greater. Again, gross trapping far exceeded that measured by organ analysis. There was evidence of a large loss of red cells and plasma into the the ligated muscles at necropsy.

Thus, all 4 dogs in shock experienced a greater reduction in total circulating cell volume than could be accounted for by net blood loss. In addition the proportion of total cells, both expected and found, in the minute vessels was less than nor- mal, and the proportion in active circulation considerably less than normal.

In $\operatorname{dog} 25-118,21.0$ per cent of the initial cell volume was unaccounted for, but only 1.3 per cent was accounted for by measured trapping in minute vessels. Since the tagged cells for final red cell volume were given with the animal in a dying state, they may not have become completely mixed, and the final total red cell volume calculation may therefore have been falsely low.

In Series III (Table III), dog 25-128, not in shock, showed no gross or minute vessel trapping of either cells or plasma, and the found volumes equalled the expected volumes, but the percentages of total and circulating cells and circulating plasma in the minute vessels were about 15 per cent below normal. There was slight gross trapping but none by organ analysis.

Dog 25-116, in early shock, showed reduction in red cell volume greater than accounted for by hemorrhage; and reductions in the normal fraction of total and circulating cells in minute vessels. Considerable plasma had been mobilized so that, although total whole blood volume was reduced, the fraction of whole blood in minute vessels was higher than normal. There was evidence of slight trapping in the minute vessels, and of 10 per cent gross trapping.

None of the other 3 dogs experienced any net blood loss. In the animal transfused, 25-129, the found blood volume was about equal to the expected; the quantity of total cells and of plasma in the minute vessels was above normal, and the quantity of circulating cells in minute vessels only slightly below normal. Five per cent of the initial cell volume was found trapped in the minute vessels, by tissue analysis, and 4 per cent by gross volume measurements. The quantity of trapped cells was 27 per cent of the total cells in the minute vessels. About 7 per cent of the expected plasma volume was unaccounted for.

Similar but more severe changes were found in the tourniquet dog (25-132). Found circulating cell volume was 90 per cent of expected; plasma volume, 42 per cent; and whole blood volume, 60 per cent of expected. The portion of total cells in the minute vessels was normal, but only 32 per cent of the normal fraction was in active circulation. The minute vessels contained only 63 per cent of the normal complement of circulating 
plasma, and as a result only 74 per cent of the normal quantity of whole blood was flowing through the minute vessels. Five per cent of the initial cell volume and 56 and 38 per cent of the initial plasma and whole blood volume were unaccounted for.

Thus in only 2 of the above experiments (25118 and 120) was the amount of trapped cells unaccounted for by organ analysis greater than could be explained by whole blood loss into damaged areas or intestinal hemorrhage.

The actual quantities of red cells trapped within the minute vessels is a very small fraction of both the expected and found red cell volumes. These quantities of trapped red cells, hawever, represent a very large percentage of the total cells within the minute vessels.

The quantity of all the cells and plasma in the body, as determined by gross plasma (dye) and circulating red cell (radio-iron) measurements; and of the cells and plasma in the minute vessels (by analyses of tissue samples for radioactive iron and radioactive iodine) were measured for dogs in Series III. The arithmetic difference between whole body and minute vessel blood may be termed "large vessel blood." These radioactivity data permit of calculating the hematocrits of (1) the blood in minute vessels of individual organs, and hence the average weighted hematocrit of all the blood in the minute vessels of the organ analyzed, (2) the hematocrit of all the blood in the body, and (3) the hematocrit of that portion of blood contained only in the large vessels. These values are shown in Table VI, in comparison with corresponding values found in 5 normal dogs. They serve to bring out another characteristic disturbance in the circulation in shock, illustrated in Figure 1. The upper left-hand figure represents the normal percentage, in terms of degrees, of total blood volume contained within the large and minute vessels, the hematocrit of the blood being indicated by the cross-hatched inner circles. The other figures represent the degree of change from the normal relationship in the 5 dogs in Series III. In each case the entire circle represents the final found total blood volume; the larger angular section, the percentage of whole blood in the larger vessels; and the smaller section, the percentage of whole blood in the minute vessels. The cross-hatched sections again represent the hematocrit of the blood in the 2 compartments. The black sections in the centers of the circles represent the percentage of total minute vessel cells trapped out of circulation. Thus the graphs portray changes in distribution of cells and plasma within the vascular bed.

Dog 25-128 was not in shock; the percentage of final total blood volume in the minute vessels was normal, and the hematocrit of that blood was

TABLE VI

Hematocrits of blood in right auricle, large vessels, the whole body, and minute vessels; and the ratio of these hematocrits to the auricular hematocrit

\begin{tabular}{|c|c|c|c|c|c|c|c|c|c|c|c|c|}
\hline \multirow[b]{3}{*}{$\begin{array}{l}\text { Auricular hematocrit } \\
\text { Large vessel hematocrit } \\
\text { Whole body hematocrit } \\
\text { Minute vessel hematocrit } \\
\text { Minute vessel hematocrit } \\
\text { (excluding spleen) }\end{array}$} & \multicolumn{12}{|c|}{ Normal dogs } \\
\hline & \multicolumn{2}{|c|}{$25-131$} & \multicolumn{2}{|c|}{$25-127$} & \multicolumn{2}{|c|}{ 25-114 } & \multicolumn{2}{|c|}{$25-113$} & \multicolumn{2}{|c|}{$25-111$} & \multicolumn{2}{|c|}{ Average } \\
\hline & \begin{tabular}{|c|} 
per cent \\
42.3 \\
40.7 \\
40.0 \\
37.6 \\
26.3
\end{tabular} & $\begin{array}{l}R \\
1.00 \\
0.96 \\
0.95 \\
0.89 \\
0.62\end{array}$ & $\begin{array}{c}\text { per cent } \\
33.8 \\
31.3 \\
32.9 \\
25.9\end{array}$ & $\begin{array}{c}R \\
1.00 \\
0.93 \\
0.97 \\
0.77\end{array}$ & $\begin{array}{c}\text { per cent } \\
50.0 \\
47.3 \\
44.3 \\
\\
16.5\end{array}$ & $\begin{array}{c}R \\
1.00 \\
0.95 \\
0.88 \\
0.33\end{array}$ & \begin{tabular}{|c|} 
per cent \\
46.7 \\
45.2 \\
45.3 \\
35.8 \\
24.6
\end{tabular} & $\begin{array}{c}R \\
1.00 \\
0.97 \\
0.97 \\
0.77 \\
0.53\end{array}$ & \begin{tabular}{|c|} 
per cent \\
44.6 \\
32.3 \\
31.9 \\
24.2 \\
22.8
\end{tabular} & $\begin{array}{l}R \\
1.00 \\
0.73 \\
0.71 \\
0.54 \\
0.51\end{array}$ & \begin{tabular}{|c|} 
per cent \\
43.5 \\
39.4 \\
38.9 \\
32.5 \\
23.4
\end{tabular} & $\begin{array}{l}R \\
1.00 \\
0.90 \\
0.90 \\
0.75 \\
0.54\end{array}$ \\
\hline & \multicolumn{12}{|c|}{ Dogs in experimental shock } \\
\hline & \multicolumn{2}{|c|}{$25-128$} & \multicolumn{2}{|c|}{ 25-116 } & \multicolumn{2}{|c|}{$25-129$} & \multicolumn{2}{|c|}{$25-130$} & \multicolumn{2}{|c|}{ 25-132 } & & \\
\hline $\begin{array}{l}\text { Auricular hematocrit } \\
\text { Large vessel hematocrit } \\
\text { Whole body hematocrit } \\
\text { Minute vessel hematocrit } \\
\text { Minute vessel hematocrit } \\
\text { (excluding spleen) }\end{array}$ & $\begin{array}{l}35.1 \\
28.5 \\
28.1 \\
25.9 \\
25.0\end{array}$ & $\begin{array}{l}1.00 \\
0.81 \\
0.80 \\
0.74 \\
0.71\end{array}$ & $\begin{array}{l}43.1 \\
32.2 \\
28.8 \\
15.8 \\
15.2\end{array}$ & $\begin{array}{l}1.00 \\
0.75 \\
0.67 \\
0.37 \\
0.35\end{array}$ & $\begin{array}{l}62.5 \\
54.0 \\
52.3 \\
44.4 \\
44.4\end{array}$ & $\begin{array}{l}1.00 \\
0.86 \\
0.84 \\
0.71 \\
0.71\end{array}$ & $\begin{array}{l}48.4 \\
38.1 \\
36.1 \\
23.1\end{array}$ & $\begin{array}{l}1.00 \\
0.79 \\
0.75 \\
0.48\end{array}$ & $\begin{array}{l}67.5 \\
65.0 \\
60.5 \\
43.2 \\
43.2\end{array}$ & $\begin{array}{l}1.00 \\
0.96 \\
0.89 \\
0.64 \\
0.64\end{array}$ & $\begin{array}{l}51.3 \\
43.6 \\
41.2 \\
32.3 \\
30.2\end{array}$ & $\begin{array}{l}1.00 \\
0.85 \\
0.80 \\
0.63 \\
0.59\end{array}$ \\
\hline
\end{tabular}


only slightly elevated. The hematocrit of large vessel blood was definitely below normal. There was no trapping. Arterial hematocrit was 35.1.

Dog 25-116 was in early shock. The percentage of whole blood in the minute vessels was in- creased, the hematocrit of that blood was below normal, and there was slight trapping. The hematocrit of large vessel blood was subnormal, and the arterial hematocrit was 43.1.

Dog 25-129 died in shock after a large trans-
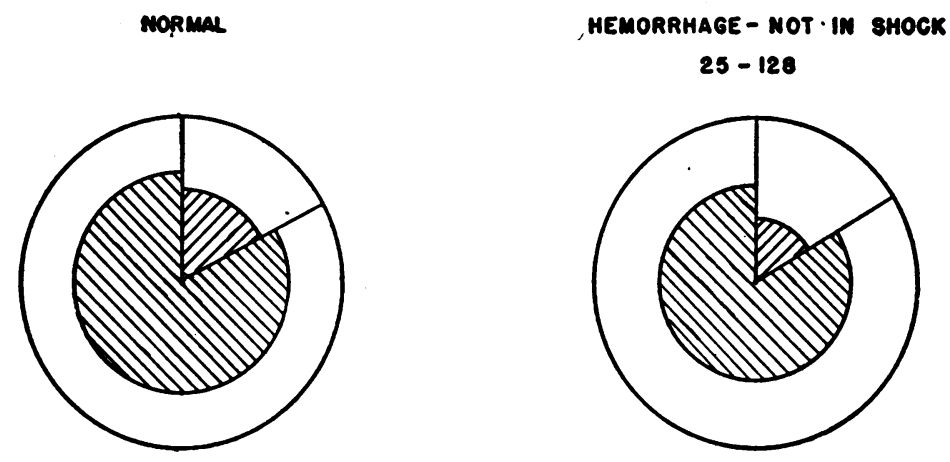

MEMORRHAGE- EARLY SHOCK

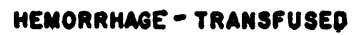

25- 116

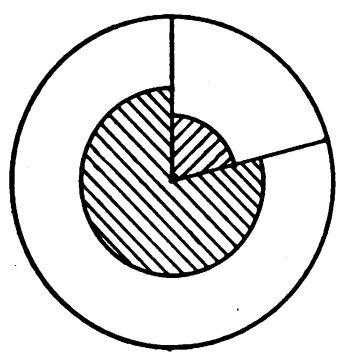

FATAL 25-129 SHOGK

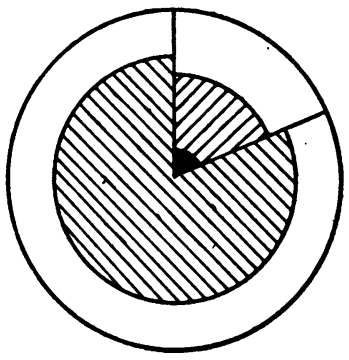

BURN-FATAL SHOGK

TOURNIQUET ; FATAL, SHOCK $25-130$ 25 - 132
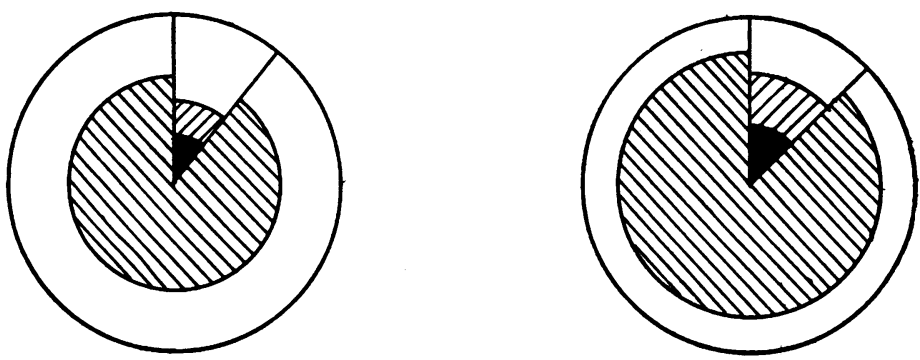

Fig. 1. Repistribution of Cells and Plasma Between Large and Minute Vessels in Shock

The whole circles represent the total whole blood volume as finally determined by dye plasma, radio-iodo-plasma, and radio-iron red cell volume measurements. The larger segments represent whole blood in all the large vessels; the smaller, whole blood in all the minute vessels. In both segments, the cross-hatched areas represent the red cell fraction of whole blood. The inner black segments represent the fraction of total cells trapped in all the minute vessels. For discussion of changes in the several types of shock, see text. 


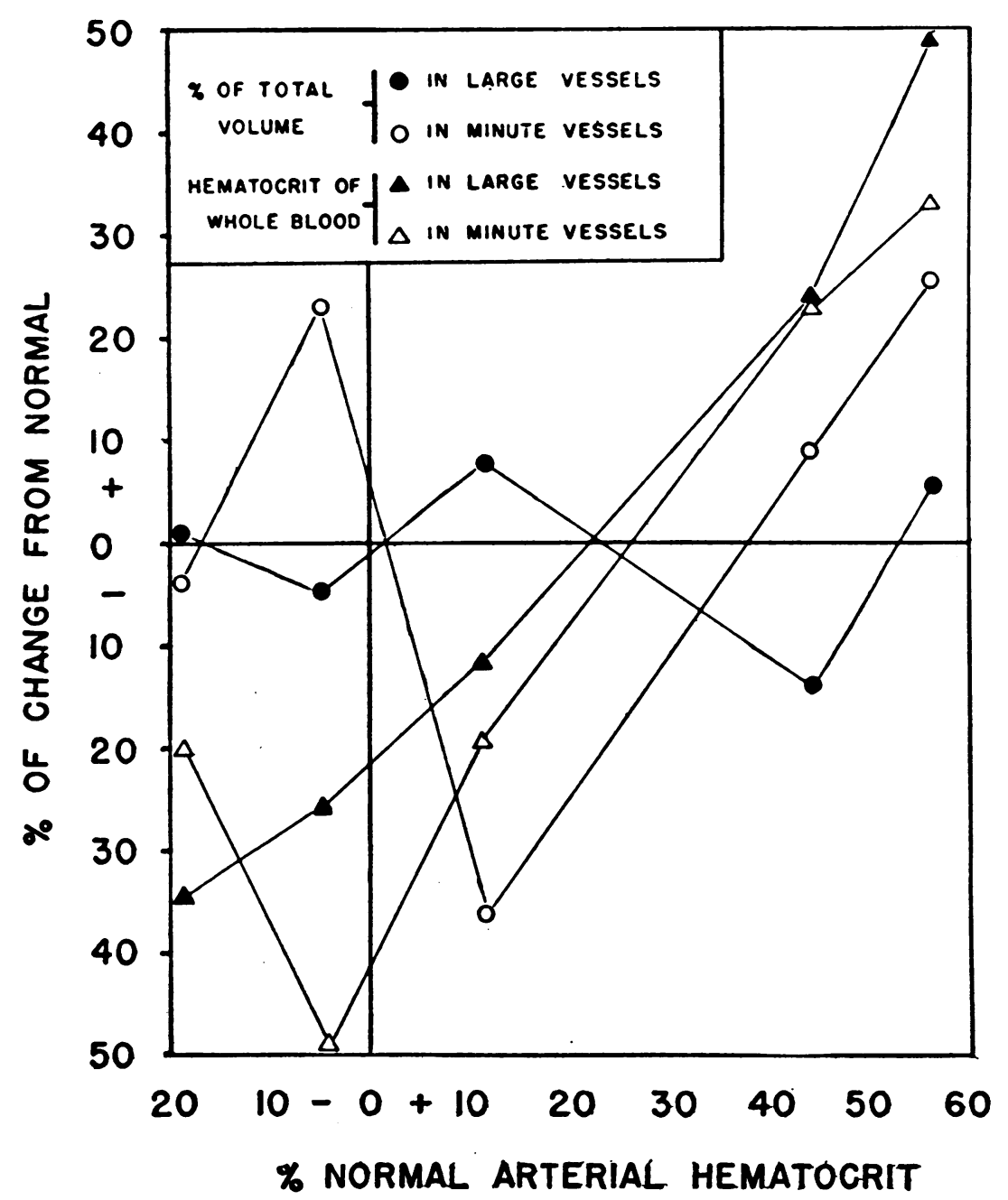

Fig. 2. Redistribution of Blood in Large and Minute Vessels in Relation to Arterial Hematocrit Level in Shock

The change from the normal proportion of whole blood in all the large and minute vessels in shock bears no relation to hemodilution or hemoconcentration. The change from the normal hematocrit of blood in both the large and minute vessels is related to arterial hematocrit level, the hematocrits being low in hemodilution (due here to hemorrhage) and rising progressively with increasing hemoconcentration (here due to plasma loss).

fusion. The percentage of total final blood volume in the minute vessels was well above normal, as was also the hematocrit, and extensive trapping occurred. The hematocrit of large vessel blood was considerably higher than normal. The arterial hematocrit was 62.5 .

Dog 25-130 died in shock of severe burns. The minute vessel whole blood percentage was reduced, the hematocrit was normal, but 40 per cent of the cells were trapped. The large vessel hematocrit was normal and the arterial hematocrit was 48.4 .

Finally, Dog 25-132 succumbed to tourniquet shock. The minute vessel whole blood percentage was reduced, the hematocrit of this blood was high, and there was considerable trapping. The large vessel hematocrit was extremely high, and the arterial hematocrit was 67.5 .

Thus in the 4 animals in recognizable clinical shock there was not only a reduction in total vol- 
ume, with varying degrees of trapping, but an abnormal distribution of whole blood between large and small vessels, and a resulting distortion of the hematocrit of large and minute vessel blood.

The graphs also emphasize the extremely small fraction of total red cell volume that need be trapped in minute vessels to bring about the reduction in capillary flow associated with irreversible shock.

The degree of abnormal distribution of blood and the distortion in large and minute vessel hematocrit are shown in relation to the level of arterial hematocrit in Figure 2, expressed as percentage deviation from average normal values. Fluctuations in either large or minute vessel whole blood content bore no relationship to arterial hematocrit level. There was, however, a definite direct linear relationship between arterial hematocrit and both large and small vessel hematocrits.

The degree of trapping found in the minute vessels of the organs analyzed did not appear to be related to the amount of external blood loss, as shown in Figure 3. The lowest ratio of circulating to total red cells was found in the burned dog which was bled only 14 per cent of its total volume; the highest, in an animal bled 48 per cent of its volume. The phenomenon is, however, apparently related to the fall in mean arterial pressure, as is also shown in Figure 3. Four dogs with ratios higher than 0.80 had a decline in mean arterial pressure of less than $30 \mathrm{~mm}$. $\mathrm{Hg}$. The remaining 6 dogs, with ratios lower than 0.80 , experienced declines of greater than $65 \mathrm{~mm}$. $\mathrm{Hg}$ in mean arterial pressure. It has been pointed out (38) that the blood pressure may be a misleading guide to the state of the animal when the blood viscosity is abnormally high due to a high hematocrit. In such event, the blood flow, as indicated by cardiac output, is very poor in spite of nearly normal blood pressure.

Thus, 2 observations appear to be of value in the clinical diagnosis of the presence of, and appraisal of, the severity of capillary trapping in shock: hemoconcentration and arterial hypotension.

It appears probable that while reduction in total volume may be the precipitating cause of peripheral vascular collapse, this simple oligemia alone does not bring about the changes usually classified as "irreversible." It seems far more probable that the reduced flow of whole blood through the nutrient capillaries of all the organs results in anoxia, and starvation of parenchymal cells. If sufficient in degree and duration, impairment of cellular function and eventually death are inevitable sequelae.

If this conception be true, then effective therapy should be directed not only at restoration of re-
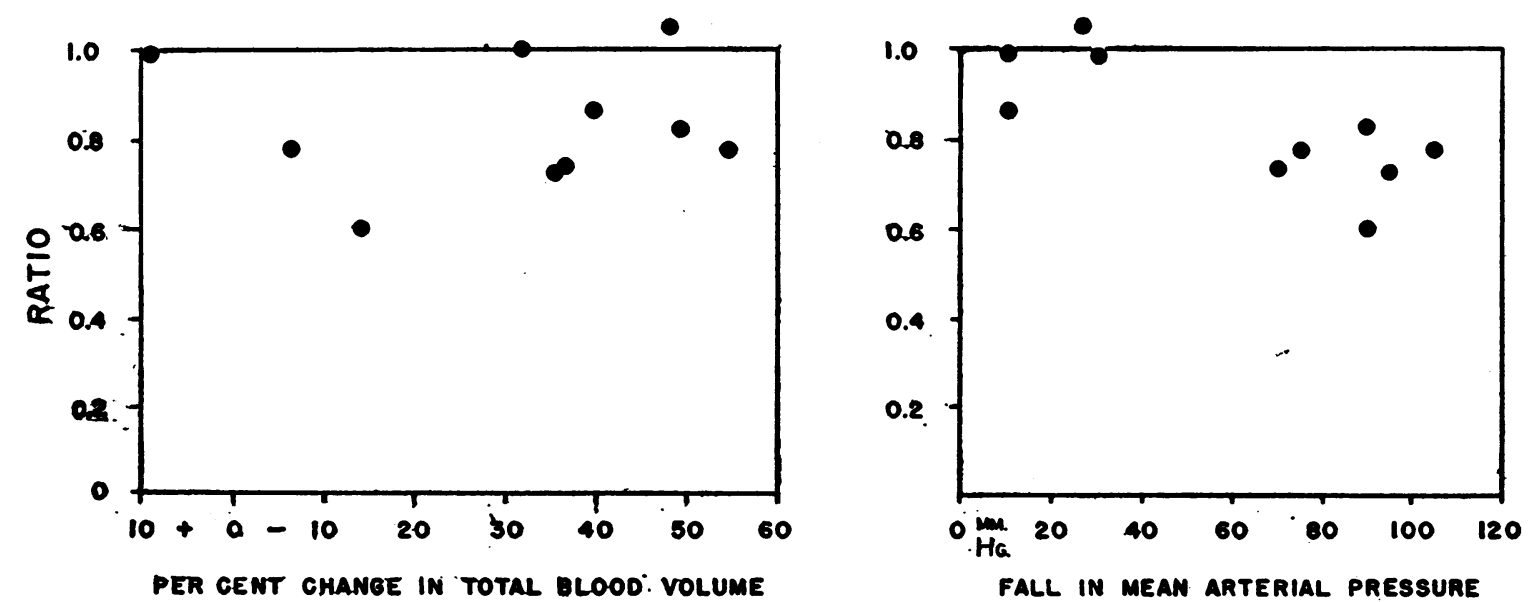

Fig. 3. The Ratio of Circulating to Total Red Cells in Minute Vessels in Relation to Reduction in Total Blood Volume and Fall in Mean Arterial Pressure

Reduction in total blood volume alone does not appear to be a causative factor in bringing about trapping of red cells in minute vessels. The degree of trapping does, however, become increasingly severe with progressive fall in mean arterial pressure. 


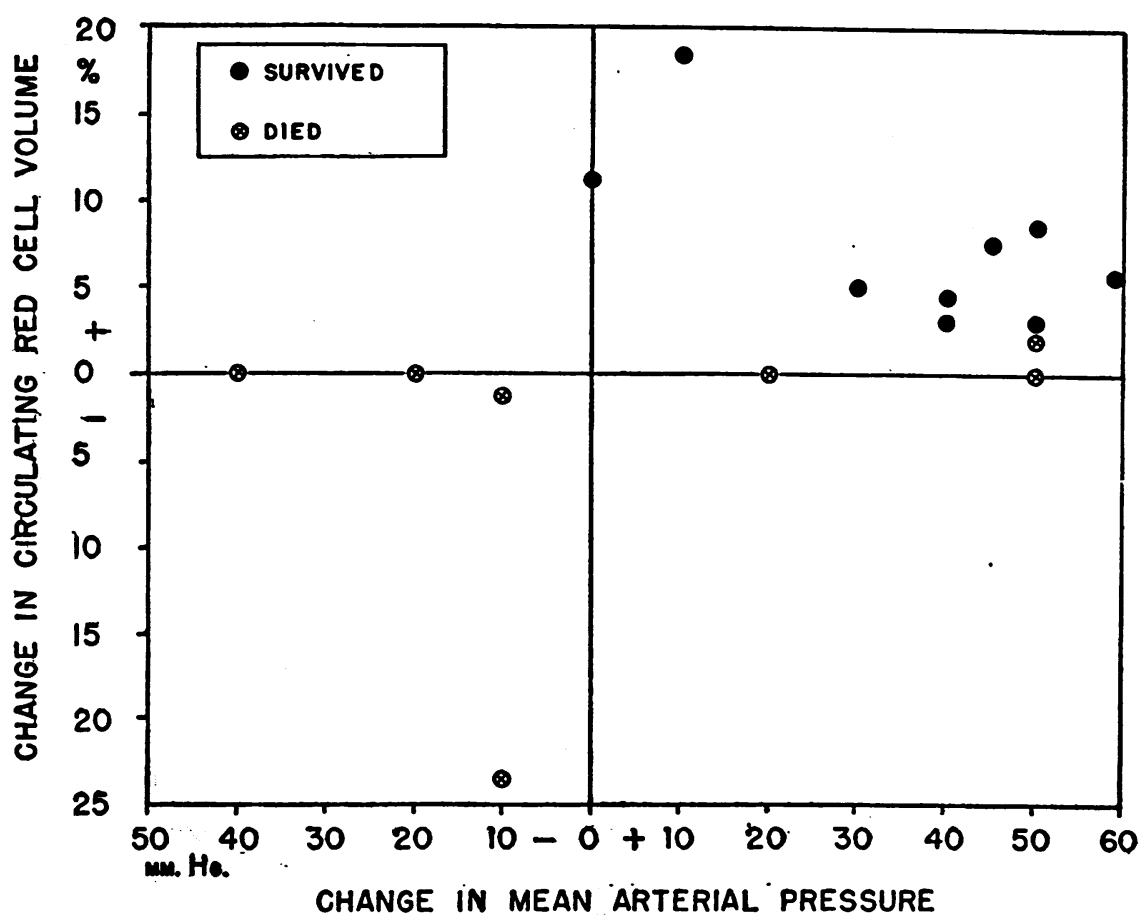

Fig. 4. Change in Total Circulating Red Cell Volume in Relation to Change in Mean Arterial Pressure in Tourniquet Shock after Albumin THERAPY

All of the 8 surviving dogs mobilized red cells, as evidenced by increases in circulating red cell volume, and 7 had sustained rises in mean arterial pressure. Slight increases in red cell volume occurred in only 2 of the 8 dogs that succumbed, although 4 had sustained rises in pressure.

duced total cell and plasma volume, but in restoration of normal flow through the entire vascular bed. Following the treatment of shock with protein solutions, there should be an increase, over shock levels, not only in plasma volume but in circulating red cell volume if therapy were to be considered successful.

Data obtained in Series IV are of interest. Most of the animals showed increases in mean arterial pressure immediately after the administration of albumin. These pressure rises were fairly well maintained in the survivors but were transient in those that died. There was no relationship between degree of fall in auricular hematocrit and the percentage change from expected circulating red cell volume. The fall in hematocrit in the dogs that died was as great as in the dogs that survived. The improvement in circulating red cell volume was however related to the change in mean arterial pressure. All of the 8 surviving dogs had increases in red cell volume. In 1 the pressure was unchanged but in the other 7, a rise of from 10 to $60 \mathrm{~mm}$. $\mathrm{Hg}$ was sustained. Of the 8 dogs that died, 4 had increases in pressure of from 20 to $50 \mathrm{~mm}$. $\mathrm{Hg}$, and 4 had decreases of from 10 to $40 \mathrm{~mm}$. $\mathrm{Hg}$. Three dogs had elevations in pressure of $50 \mathrm{~mm}$. $\mathrm{Hg}$, ac.companied by slight increases in red cell volume, but died.

Most of the survivors showed percentage increases in red cell volume that were within the limit of error of the technique of cell volume measurement used. However, the percentage increases are of the same order of magnitude as the percentages of red cells found trapped in minute vessels in Series II and III. The consistent finding of an augmented circulating cell volume after therapy in all the surviving animals is in keeping with the possibility that one effect of successful treatment was to restore the circulation through 
the minute vessels to normal, with the resultant flushing back into circulation of trapped cells. Failure of this in the animals that died is of almost equal significance.

In a previous communication (26) it was noted that in the normal dog, the hematocrits of the blood in large vessels and in all the body are approximately equal, but less than the auricular and greater than the minute vessel hematocrits. It was stated above that the ratios of these hematocrits to the auricular hematocrit explained satisfactorily why the dye plasma hematocrit technique always gives a value of the red cell volume some 20 per cent higher than does the radio-iron technique.

In the shocked dogs, the ratios of the large and minute vessel hematocrit to the auricular hematocrit were changed, that of the large vessel hematocrit being 0.83 , and that of the minute vessel hematocrit being 0.61 .

In the 5 dogs in Series III, the percentage of total circulating whole blood in the minute vessels averaged 16 per cent. Then

$$
\begin{aligned}
0.84 \times 0.83= & 0.697 \\
0.16 \times 0.61= & \frac{0.097}{0.794}=\frac{\text { Vrr }}{\operatorname{Vrpd}} \text { or } \frac{\operatorname{Vrpd}}{\operatorname{Vrr}}=1.26 .
\end{aligned}
$$

Since here again Vrpd is based on the plasma volume and auricular hematocrit, it follows that Vrr will be about 20 per cent lower than Vrpd. In other words, the red cell volume as measured by the dye technique will be about 26 per cent higher than by the radio-iron technique.

In a series of 28 simultaneous measurements of cell volume by both techniques in dogs in varying degrees of shock, in which auricular hemaocrits ranged from 19 to 69 , averaging 43.7, the average ratio of $\frac{\mathrm{Vrpd}}{\mathrm{Vrr}}$ was found to be 1.32 .

Thus, the former technique not only over-estimates circulating red cell volume in the normal state, but gives an even higher degree of error in peripheral vascular collapse, regardless of the presence of hemodilution or hemoconcentration.

\section{COMMENT}

These studies are in keeping with the findings of several authors on the circulatory changes in shock. The gross volume studies confirm the conclusions of Noble and Gregersen (22) that reduction in blood volume is due to loss of both cells and plasma: whole blood. In these controlled experiments the loss of whole blood was always more than the measured external blood loss. In certain types of insult (burns, tourniquet and toxins), some of this whole blood was undoubtedly lost in damaged areas or in the intestinal tract. The other site of whole blood "loss" lies within the capillary bed. Chambers et al (39) found cessation of blood flow in the capillaries in the mesentery of dogs in shock. The studies herein reported indicate that this phenomenon is not confined to sites of injury, or to abdominal viscera, but that it is a widespread phenomenon occurring in all organs throughout the body.

Since the methods of volume measurement used are dynamic, they reveal changes in total blood flow through capillary beds of all the organs. The net effect of trapping is a reduction of flow through vital areas. The resulting anoxia, failure in nutrition and waste disposal, if continued for long periods, is not compatible with the continued existence of certain parenchymal cells. For instance, it has been shown (37) that liver cells in dogs in hemorrhagic shock may be the earliest to show the effects of the reduced blood flow characteristic of peripheral vascular collapse.

Since the capillaries of organs normally contain less than $1 / 5$ of all the total circulating cells and plasma, the trapping of only $1 / 20$ of the total blood volume may bring about a reduction in flow to $1 / 4$ or $1 / 3$ of normal. Extensive trapping may be present in the absence of measurable hemoconcentration or hemodilution, or with a normal hematocrit.

Effective therapy should be directed not only towards restoration of total blood volume, but to the resumption of normal capillary flow. Objective evidence of effective therapy lies in the restoration and maintenance of normal hematocrit and normal arterial pressure.

\section{CONCLUSIONS}

1. Measurements of the total circulating red cell and plasma volume, and of the distribution of blood in large and minute vessels were made in dogs in experimental shock, by means of tech- 
niques employing Evans blue, 2 isotopes of radioactive iron, and radioactive iodine. The following characteristics of the circulation in shock have been demonstrated.

2. There is always a greater reduction in circulating red cells and plasma than can be accounted for by measured external blood loss.

3. A part of this discrepancy in blood volume may be lost into damaged areas or by intestinal bleeding in certain types of shock.

4. Regardless of etiology, there is a widespread trapping of red cells within the minute vessels of all the organs in the body.

5. The effect of this trapping is a reduction in capillary blood flow through all organs.

6. Since the normal capillary blood content is less than 20 per cent of the total volume, the trapping of even a small portion thereof may result in a fatal reduction in capillary flow.

7. There is an abnormal distribution of whole blood between large and minute vessels which is not reflected by changes in the arterial hematocrit.

8. There are marked deviations from normal in the hematocrit of large and small vessel blood, and these are directly related to changes in the arterial hematocrit.

9. The degree of red cell trapping present does not parallel the reduction in total blood volume, but is related to the reduction in mean arterial pressure. However, this correlation between trapping and arterial pressure may not apply when the hematocrit is abnormally high.

10. The findings indicate that the therapy of shock should be directed not only towards restoration of total blood volume, but also towards the resumption and maintenance of normal capillary flow.

\section{ACKNOWLEDGMENT}

Acknowledgment for technical assistance is due Miss Martha Goldberg, Miss Florence Tytell, Mrs. Reggie Burt and Thomas Barnett.

\section{BIBLIOGRAPHY}

1. Keith, N. M., Rowntree, L. G., and Geraghty, J. T., $A$ method for the determination of plasma and blood volume. Arch. Int. Med., 1915, 16, 547.

2. Robertson, O. H., and Bock, A. V., Blood volume in wounded soldiers. I. Blood volume and related blood changes after hemorrhage. J. Exper. Med., 1919, 29, 139.
3. Robertson, O. H., and Bock, A. V., Memorandum on blood volume. Med. Research Committee Special Report, No. 25, 1918.

4. Gregersen, M. I., Traumatic shock. Bull. New York Acad. Med., 1943, 19, 666.

5. Cannon, W. B., Traumatic Shock. D. Appleton and Company, New York, 1923.

6. Blalock, A., Experimental shock. The cause of low blood pressure produced by muscle injury. Arch. Surg., 1930, 20, 959.

7. Blalock, A., Trauma to the intestines. The importance of the local loss of fluid in the production of low blood pressure. Arch. Surg., 1931, 22, 314.

8. Moon, V. H., Dynamics of Shock and its Clinical Implications. Lea and Febiger, Philadelphia, 1942.

9. Gibson, J. G., 2nd, and Evans, W. A., Jr., Clinical studies of the blood volume. I. Clinical application of a method employing the azo dye "Evans blue" and the spectrophotometer. J. Clin. Invest., 1937, 16, 301.

10. Gregersen, M. I., and Stewart, J. D., Simultaneous determination of the plasma volume with T-1824, and the "available fluid" volume with sodium thiocyanate. Am. J. Physiol., 1939, 125, 142.

11. Davis, L. J., Determination of blood volume in man with "Evans" blue ("T-1824"). Edinburgh M. J., 1942, 49, 465.

12. Gibson, J. G., 2nd, and Branch, C. D., Blood volume changes during surgical procedures. Surg., Gynec. and Obst., 1937, 65, 741.

13. Gibson, J. G., 2nd, and Kopp, I., Studies in the physiology of artificial fever. I. Changes in the blood volume and water balance. J. Clin. Invest., 1938, 17, 219.

14. Keeley, J. L., Gibson, J. G., 2nd, and Pijoan, M., The effect of thermal trauma on blood volume, serum protein, and certain blood electrolytes: An experimental study of the effect of burns. Surgery, 1939, 5, 872.

15. Dunphy, J. E., and Gibson, J. G., 2nd, The effect of replacement therapy in experimental shock. Surgery, 1941, 10, 108.

16. Scudder, J., Shock: Blood Studies as a Guide to Therapy. J. B. Lippincott Company, Philadelphia, 1940.

17. Harkins, H. N., Recent advances in the study and management of traumatic shock. Surgery, 1941, 9, 231.

18. Wiggers, C. J., The present status of the shock problem. Physiol. Rev., 1942, 22, 74.

19. Mahoney, E. B., Kingsley, H. D., and Howland, J. W., The treatment of experimental shock by the intravenous injection of dilute, normal, and concentrated plasma. Surg., Gynec. and Obst., 1942, 74, 319.

20. Richards, D. W., Jr., The circulation in traumatic shock in man. The Harvey Lectures, 1943-1944, p. 217. The Science Press Printing Company, Lancaster, $\mathrm{Pa}$. 
21. Evans, E. I., Hoover, M. J., James, G. W., and Alm, T., Studies on traumatic shock. I. Blood volume changes in traumatic shock. Ann. Surg., 1944, 119, 64.

- 22. Noble, R. P., and Gregersen, M. I., with the technical assistance of Porter, P. M., and Buckman, A., Blood volume in clinical shock. II. The extent and cause of blood volume reduction in traumatic, hemorrhagic, and burn shock. J. Clin. Invest., 1946, 25, 172.

23. Fine, J., and Seligman, A. M., Traumatic shock: IV. A study of the problem of the "lost plasma" in hemorrhagic shock by the use of radioactive plasma protein. J. Clin. Invest., 1943, 22, 285.

24. Fine, J., and Seligman, A. M., Traumatic shock. An experimental study including evidence against the capillary leakage hypothesis. Ann. Surg., 1943, 118, 238.

25. Fine, J., and Seligman, A. M., Traumatic shock. VII. A study of the problem of the "lost plasma" in hemorrhagic, tourniquet, and burn shock by the use of radioactive iodo-plasma protein. J. Clin. Invest., 1944, 23, 720.

26. Gibson, J. G., 2nd, Peacock, W. C., Seligman, A. M., and Sack, T., Circulating red cell volume measured simultaneously by the radioactive iron and dye methods. J. Clin. Invest., 1946, 25, 838.

27. Root, G. T., and Mann, F. C., An experimental study. of shock with special reference to its effect on the capillary bed. Surgery, 1942, 12, 861.

28. Chambers, R., Zweifach, B. W., and Lowenstein, B. E., The peripheral circulation during the tourniquet shock syndrome in the rat. Ann. Surg., 1944, 20, 791.

29. Gibson, J. G., 2nd, Seligman, A. M., Peacock, W. C., Aub, J. C., Fine, J., and Evans, R. D., The distribution of red cells and plasma in large and minute vessels of the normal dog, determined by radioactive isotopes of iron and iodine. J. Clin. Invest., 1946, 25, 848.

30. Gibson, J. G., 2nd, and Evelyn, K. A., Clinical studies of the blood volume. IV. Adaptation of the method to the photoelectric microcolorimeter. J. Clin. Invest., 1938, 17, 153.

31. Gibson, J. G., 2nd, Weiss, S., Evans, R. D., Peacock, W. C., Irvine, J. W., Jr., Good, W. M., and Kip, A. F., The measurement of the circulating red cell volume by means of two radioactive istopes of iron. J. Clin. Invest., 1946, 25, 616.

32. Duncan, G. W., and Blalock, A., The uniform production of experimental shock by crush injury: possible relationship to clinical crush syndrome. Ann. Surg., 1942, 115, 684.

33. Nathanson, I. T., Nutt, A. L., Pope, A., Zamecnik, P. C., Aub, J. C., Brues, A. M., and Kety, S. S., The toxic factors in experimental traumatic shock. I. Physiologic effects of muscle ligation in the dog. J. Clin. Invest., 1945, 24, 829.

34. Fine, J., Frank, H. A., and Seligman, A. M., Traumatic shock. VIII. Studies in the therapy and hemodynamics of tourniquet shock. J. Clin. Invest., 1944, 23, 731.

35. Freedberg, A. S., Haimovici, H. (by invitation), and Blumgart, H. L., The cardiovascular dynamics in shock due to infection. J. Clin. Invest., 1944, 23, 930.

36. Aub, J. C., Brues, A. M., Kety, S. S., Nathanson, I. T., Nutt, A. L., Pope, A., and Zamecnik, P. C., The toxic factors in experimental traumatic shock. IV. The effects of the intravenous injection of the effusion from ischemic muscle. J. Clin. Invest., 1945, 24, 845.

37. Frank, H. A., Seligman, A. M., and Fine, J., Traumatic shock. XIII. The prevention of irreversibility in hemorrhagic shock by vivi-perfusion of the liver. J. Clin. Invest., 1946, 25, 22.

38. Seligman, A. M., Frank, H. A., and Fine, J., Traumatic shock. XII. Hemodynamic effects of alterations of blood viscosity in normal dogs and in dogs in shock. J. Clin. Invest., 1946, 25, 1.

39. Chambers, R., Zweifach, B. W., and Lowenstein, B. E., Circulatory reactions of rats traumatized in the Noble-Collip drum. Am. J. Physiol., 1943, 139, 123. 